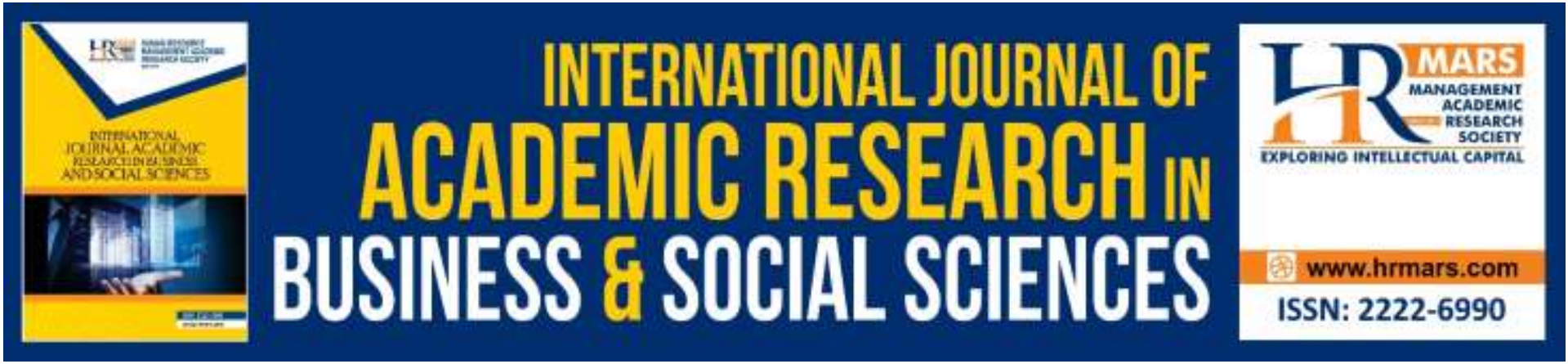

\title{
Learning Management System (LMS) in Teaching and Learning
}

MJA Rahman, Daud, M. Y. \& Ensimau, N. K

To Link this Article: http://dx.doi.org/10.6007/IJARBSS/v9-i11/6717

DOI: $10.6007 /$ IJARBSS/v9-i11/6717

Received: 06 October 2019, Revised: 27 October 2019, Accepted: 09 November 2019

Published Online: 25 November 2019

In-Text Citation: (Rahman, Daud, \& Ensimau, 2019)

To Cite this Article: Rahman, M. J. A., Daud, M. Y., \& Ensimau, N. K. (2019). Learning Management System (LMS) in Teaching and Learning. International Journal of Academic Research in Business and Social Sciences, 9(11), 1529-1535.

Copyright: (C) 2019 The Author(s)

Published by Human Resource Management Academic Research Society (www.hrmars.com) This article is published under the Creative Commons Attribution (CC BY 4.0) license. Anyone may reproduce, distribute, translate and create derivative works of this article (for both commercial and non-commercial purposes), subject to full attribution to the original publication and authors. The full terms of this license may be seen at: http://creativecommons.org/licences/by/4.0/legalcode

Vol. 9, No. 11, 2019, Pg. 1529 - 1535

Full Terms \& Conditions of access and use can be found at http://hrmars.com/index.php/pages/detail/publication-ethics 


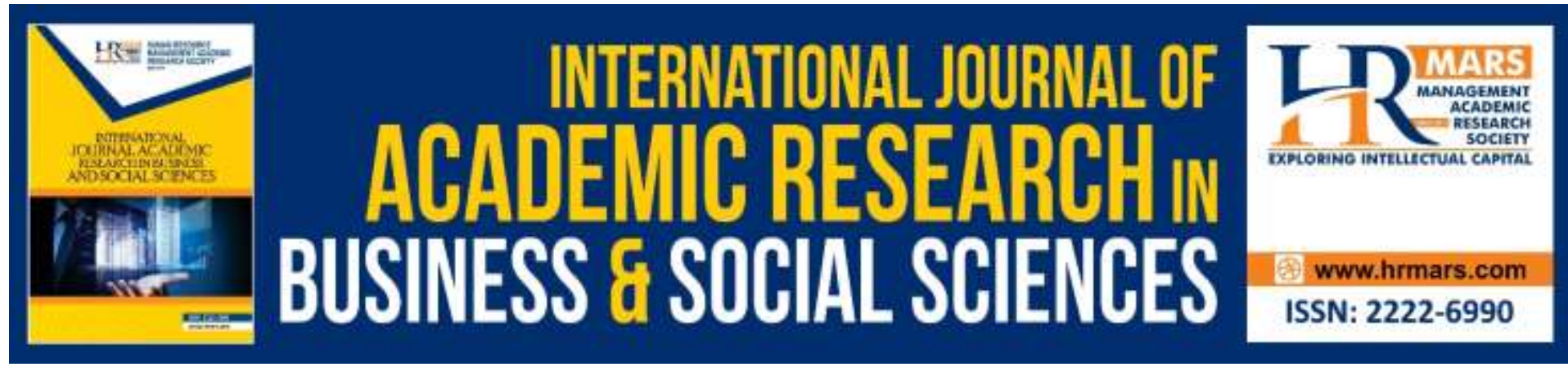

\title{
Learning Management System (LMS) in Teaching and Learning
}

\author{
MJA Rahman, Daud, M. Y. \& Ensimau, N. K \\ Faculty of Education, National University of Malaysia (UKM), Bangi, Selangor, Malaysia
}

\begin{abstract}
The study aimed to investigate the use of Learning Management System (LMS) in teaching and learning process in higher education. Specifically, this study identified the knowledge and benefits of using LMS as perceived by students studying education programs. This study involved 40 education students studying at various levels of education programs in one higher education institution and employed questionnaires to collect data. Data was analysed using descriptive statistics. The study found that students have a good knowledge on LMS and a positive view on LMS. The study suggested that LMS facilitate postgraduate students in their learning process and thus should be designed to provide a user friendly interface and navigation to support students' learning.
\end{abstract}

Keyword: Learning Management System (LMS), Online Learning \& Teaching and Learning.

\section{Introduction}

A learning management system (LMS) is a software application for the administration, documentation, tracking, reporting, and delivery of educational courses, training programs, or learning and development programs. The learning management system concept emerged directly from e-Learning. Although the first LMS appeared in the higher education sector, the majority of the LMS today focus on the corporate market. Learning Management Systems make up the largest segment of the learning system market. The first introduction of the LMS was in the late 1990s.

Learning management systems were designed to identify training and learning gaps, utilizing analytical data and reporting. LMS are focused on online learning delivery but support a range of uses, acting as a platform for online content, including courses, both asynchronous based and synchronous based. An LMS may offer classroom management for instructor-led training or a flipped classroom, used in higher education, but not in the corporate space.

\section{Literature Review}

'E-learning' was an effective platform in providing opportunities for students as well as to communicate more openly without boundaries (Susanti \& Sholeh, 2008). One of the reasons is elearning used learning management system, i.e. an application software that assists the administration, documentation, tracking, reporting and delivery of educational courses, training program or learning and development programme. According to Adobe (2009), Nasser, Cherif, \& Romanowski (2011), Islam (2016), 'e-learning' is a learning activity organized by electronic and computer systems in order to make sure the learning process can be easily conducted. 
Malaysia is moving towards a developed country and promotes e - learning as one of the ways to empower its citizenship. In the 10th Malaysia Plan, the Ministry of Higher Education Malaysia (2011) proposed the National 'e-learning' Policy of Higher Education Institutions to advance the use of technology in education. Following the policy, the government had rebuilt an online learning system or better known as 'e-learning' that enables students to manage their learning activities and personalized their learning content, as well as facilitates student-teacher interaction and provides a variation of student assessment tools (Kassim \& Khalid, 2016; Komsoon, 2019). The learning system also provides subject information, lecture notes and links to various sources of information (Harris \& Aziz, 2016). However, the learning system still have a gap for improvement. According to a recent study by Abidin \& Razak (2015), one of the main concerns raised by educators is the issue of limited current storage space which affects the educator to manage their work space as well as to complicate the teaching process. Furthermore, the regulatory issue still need to be improved as the provision of support assistance and friendly system that can help the users to understand better (Idris \& Ahmad, 2011).

\section{Research Objective}

This study aimed was to identify the level of knowledge of LMS and trend of LMS usage among education students. This study also aimed to examine the benefits of LMS as perceived by the students.

\section{Research Method}

This study employed survey research design and involved 40 education students in one of research universities in Malaysia. The samples were randomly selected among students in the faculty of education within the university. The study employed questionnaires to collect data which were developed online using the google form and later distributed via whatsapp and telegram applications. Data was recorded and analyzed using SPSS program in which descriptive statistics were used to describe and present the data.

\section{Results}

As illustrated in Figure 1 and Figure 2, most of the respondents are female (60\%) and undergraduate students (62.5\%). Table 1 illustrated that students from education programs have a good knowledge regarding LMS and use LMS extensively as teaching and learning process using LMS is widely practiced in the their learning institution. The used of LMS reduces the need for students and lecturers to meet face to face, as well as helps students to learn at their own pace and time. 
INTERNATIONAL JOURNAL OF ACADEMIC RESEARCH IN BUSINESS AND SOCIAL SCIENCES Vol. 9, No. 11, November, 2019, E-ISSN: 2222-6990 @ 2019 HRMARS

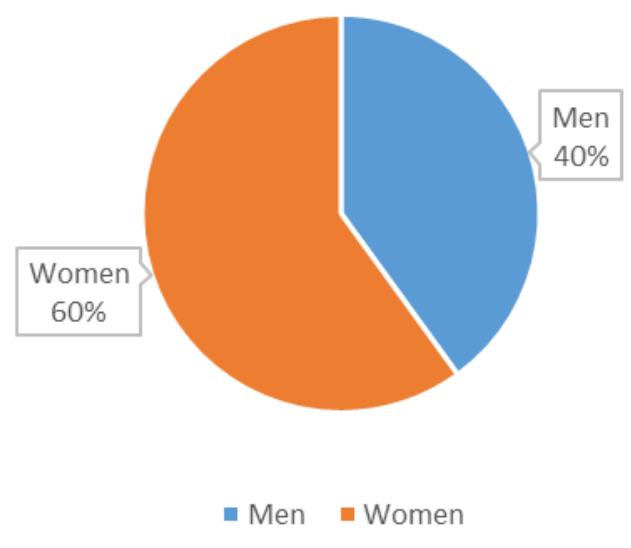

Figure 1: The distribution of respondents by gender

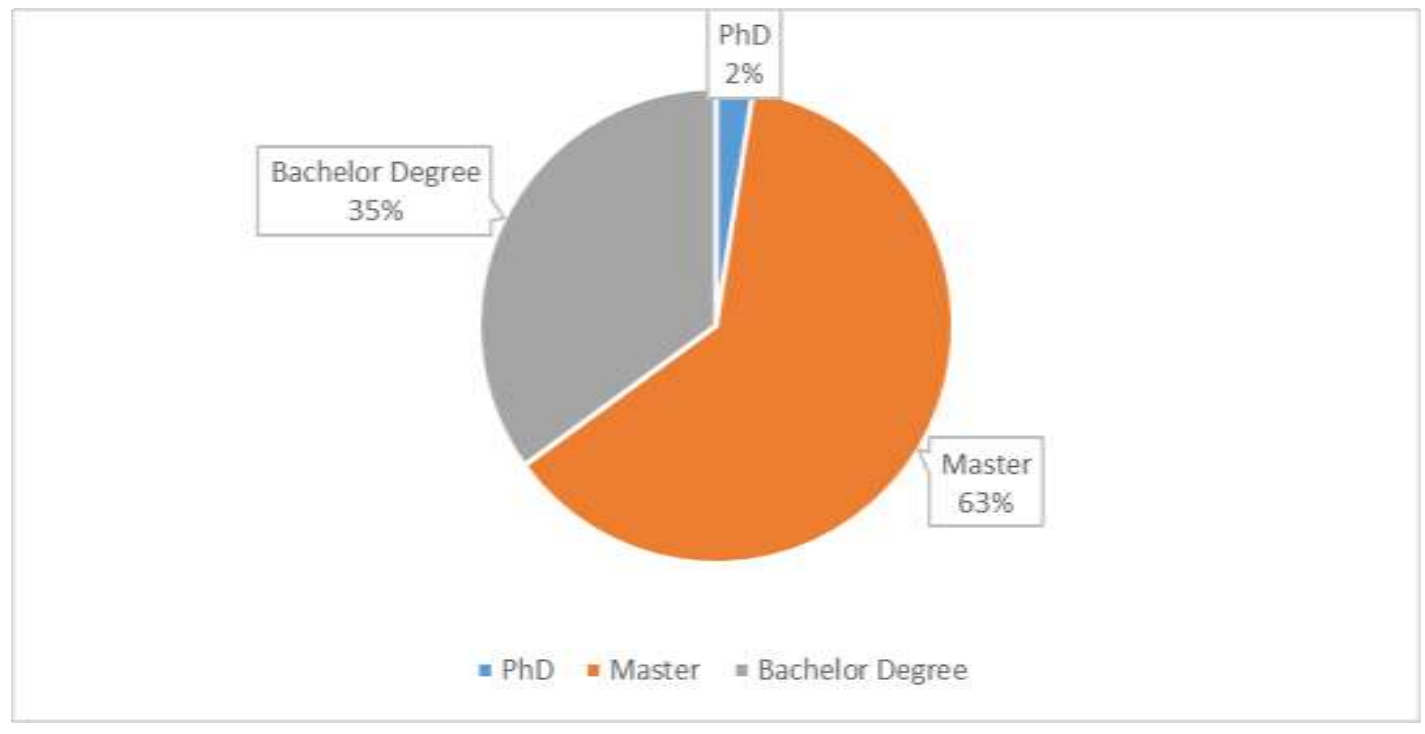

Figure 2: Respondents distribution based on education programs 
Table 1: Students' frequency and knowledge of using LMS

\begin{tabular}{|c|c|c|c|c|c|c|}
\hline Items & Min & $\begin{array}{l}\text { Strongly } \\
\text { disagree }\end{array}$ & Disagree & $\begin{array}{l}\text { Not } \\
\text { sure }\end{array}$ & Agree & $\begin{array}{c}\text { Strongly } \\
\text { agree }\end{array}$ \\
\hline $\begin{array}{l}\text { Learning Management } \\
\text { System (LMS) will be my first } \\
\text { website to be surf when I } \\
\text { open the internet }\end{array}$ & 8.00 & $\begin{array}{c}2 \\
(5 \%)\end{array}$ & $\begin{array}{c}2 \\
(5 \%)\end{array}$ & $\begin{array}{c}9 \\
(22.5 \%)\end{array}$ & $\begin{array}{c}18 \\
(45 \%)\end{array}$ & $\begin{array}{c}9 \\
(22.5 \%)\end{array}$ \\
\hline $\begin{array}{l}\text { I know about Learning } \\
\text { Management System (LMS) }\end{array}$ & 10.00 & - & $\begin{array}{c}1 \\
(2.5 \%)\end{array}$ & $\begin{array}{c}10 \\
(25 \%)\end{array}$ & $\begin{array}{c}12 \\
(30 \%)\end{array}$ & $\begin{array}{c}17 \\
(42.5 \%)\end{array}$ \\
\hline $\begin{array}{l}\text { I enjoy to used Learning } \\
\text { Management System (LMS) } \\
\text { for my learning process }\end{array}$ & 13.30 & - & - & $\begin{array}{c}4 \\
(10 \%)\end{array}$ & $\begin{array}{c}20 \\
(50 \%)\end{array}$ & $\begin{array}{c}16 \\
(40 \%)\end{array}$ \\
\hline $\begin{array}{l}\text { Learning Management } \\
\text { System (LMS) give me } \\
\text { advantafges }\end{array}$ & 10.00 & - & $\begin{array}{c}4 \\
(10 \%)\end{array}$ & $\begin{array}{c}11 \\
(27.5 \%)\end{array}$ & $\begin{array}{c}17 \\
(42.5 \%)\end{array}$ & $\begin{array}{c}8 \\
(20 \%)\end{array}$ \\
\hline $\begin{array}{l}\text { Learning Management } \\
\text { System (LMS) is easy to be } \\
\text { handle. }\end{array}$ & 8.00 & $\begin{array}{c}1 \\
(2.5 \%)\end{array}$ & $\begin{array}{c}3 \\
(7.5 \%)\end{array}$ & $\begin{array}{c}10 \\
(25 \%)\end{array}$ & $\begin{array}{c}17 \\
(42.5 \%)\end{array}$ & $\begin{array}{c}9 \\
(22.5 \%)\end{array}$ \\
\hline
\end{tabular}

\section{Discussion}

Generally, LMS helps learning institutions in conducting an effective learning process, as well as assist teachers to personalize learning to diverse learners who have various learning preferences and needs. Findings of the study suggested that LMS offers students with a variety of learning tools that help courses to become more effective. The findings also indicated that LMS is a great tool for students' learning as the system ables to streamline learning by leveraging the benefits of the Internet without neglecting the importance of a teaching staff (Azfar, 2016; Nordin et.al, 2017). LMS assists also helps lecturers to manage students and courses offered in every semester assists lecturers to assess students' learning in various learning stages using various forms of assessment ( Mat, Alias \& Muslim, 2017)

The positive view of students with regard to the use of LMS found in the study might be due to advantages of LMS that enables students to engage in learning anywhere and anytime. Such engagement could help students to think and act independently in the pursuit of knowledge, and in return increase students' learning. Futhermore, LMS is able to centralize learning and teaching strategies to better organize and deliver learning to students anytime and anywhere. According to Farhan (2011), all information on courses and training programs could be combined into one system, i.e. LMS. The system enables students to communicate actively with their lecturers and friends virtually, and by doing so assists students to learn from their lecturers and peers. However, to support such active learning, there is a need for LMS to be more user friendly and have a larger storage data capacity (Klein et al., 2019; Hutchison, 2019). 


\section{Conclusion}

Dated back to early 1900s, LMS focused on administration, documentation, tracking, reporting and delivery of courses and training programs. Featuring similar facilities, modern LMS is cloud-based and accessible anytime, anywhere. Best of all, modern LMS complies with latest educational requirement of the digital age. Not only LMS offers learning content to students, the system provides ways to personalize learning to all types of learners in the digital age such as school, college and university students, adult learners, scholars, and corporate trainees. Technology assisted learning is the way forward to support the $21^{\text {st }}$ century learning. The application LMS in any formal or non-formal education setting would be a good example to support learning in the $21^{\text {st }}$ century. The findings indicated that higher education students have excellent knowledge of LMS and acknowledge the benefits of LMS in their learning process. The study implicated that there is a need for higher education institutions to provide students with a user friendly and larger storage data capacity LMS that would facilitate active and cooperative learning among students regardless of time and place. The findings also suggested further study to identify the effectiveness of LMS usage in students' learning in comparison to conventional ways of learning as well as identify best principles for developing LMS interface for active and collaborative learning.

\section{References}

Abidin, Z. Z., \& Razak, W. M. W. A. (2015). Study on Implementation of Course Lecturer File Management System (FPK) in Enhancing the Quality of R\&D Quality at Polytechnic Merlimau, Malacca. Available from https://www.slideshare.net/malinieyrazak/kajian-implementationsistem-management-fail-pensar-kursus-fpk

Adobe. (2009) Adobe Solutions for Learning Management Systems (LMS). Available from https://www.adobe.com/content/dam/Adobe/en/education/pdfs/Ims-primer 102909.pdf

Azfar, N. (2016). Learning Management System. Available from

http://cikgunabilazfar.blogspot.my/2016/09/bab-8sistempreviewing.html (23 November 2017)

Farhan, M. (2011). Management study and student learning. Available from http://www.slideshare.net/shockgadof/group- learning-management? related $=3$

Harris, N., \& Aziz, N. (2016). Characteristics of Learning Management System (SPM). Available from https://www.slideshare.net/syafiqahharris/ciri-ciri-sistem-management-special-spp

Hutchison, W. (2019). Technological Efficiency in The Learning Management System: A Wicked Problem with Sustainability for Online Writing Instruction. Available from https://doi.org/10.1016/j.compcom.2019.102510

Idris, A. R., \& Ahmad, M. F. (2011). Development of Learning Management System (LMS) for ELearning. Journal of Science \& Mathematics Education. Pp 1-8.

Islam, M. (2016). Learning Management System. Available from

https://www.slideshare.net/mujahidislam5/8-sistem-association-learning

Kassim, N. N. M., \& Khalid, F. (2016). Choosing the Right Learning Maanagement System (LMS) for the Higher Education Institution Context a Systematic Review. International Journal of Engineering and Technology. Pp $173-182$.

Klein, C., Jaime, L., Huzefa, R., \& Adiyta, J. (2019). Learning analytics tools in higher education: Adoption at the intersection of institutional commitment and individual action. Review of Higher Education. 42, (2). Pp 565-593

Komsoom, W. K. (2011). Ontology of Ubiquitous Learning: WhatsApp Messenger Competes Successfully with Learning Management Systems (LMS) Science and Information Conference CVC 2019: Advances in Computer Vision. Pp107-117 
Mat, N., Alias, J., \& Muslim, N. (2017). Perception of Universiti Kebangsaan Malaysia Academician on the impacts of technology factor on knowledge sharing. International Bussiness Management. 11 (1). Pp 183 - 188

Ministry of Higher Education Malaysia. (2011). The 10th Malaysian Plans. Available from https://www.pmo.gov.my/dokumenattached/RMK/RMK10_Eds.pdf.

Nasser, R., Cherif, M., \& Romanowski, M. (2011). Factors that impact student usage of the learning management system in qatari schools. International Review of Research in Open and Distance Learning. 12 (6). Pp 39 - 62.

Nordin, N., Norman, H., \& Embi, M. A. (2017) Technology Acceptance of Massive Open Online Courses in Malaysia. Malaysian Journal of Distance Education.17 (2). Pp 1-16

Susanti, E., \& Sholeh, M. (2008). Designing an E-Learning Application. Journal of Technology, 1 (1): 5357.

Kavita, K., \& Hassan, N. C. (2018). Work Stress among Teachers: A Comparison between Primary and Secondary School Teachers. International Journal of Academic Research in Progressive Education and Development, 7(4), 60-66.

Masengeli O. G. W., Kiragu, D. N., Kamau, R. (2018). Effect of Financial Misstatement and Corruption on Fraud Risk among State Corporations in Mombasa County in Kenya, International Journal of Academic Research in Accounting, Finance and Management Sciences 8 (4): 39-51. 